\title{
The Impact of Food on Muslims Spiritual Development
}

\author{
Apap Nazihah*1, Bambang Samsul Arifin ${ }^{1}$ \\ ${ }^{1}$ UIN Sunan Gunung Djati Bandung \\ A.H. Nasution street no. 105, Cibiru, Bandung, West Java, 40614, Indonesia \\ e-mail: *lafafnajihah@gmail.com
}

*Correspondent Author

DOI: 10.5575/ijhar.v2i1.7802

\begin{abstract}
Islam is a religion that regulates all aspects of human beings. Muslims in Indonesia generally focus on the discussion about fiqh ibadah, but less concern on many aspects of fiqh muamalah. If it is not understood correctly, doubtful (syubhat) goods and services leading to haram might be consumed by the muslims and influenced their spiritual development. This study aims to explain the impact of food consumption on the spiritual development in Islam. The finding of this study indicates the influence of food consumed by humans might affect psychological aspects, such as emotion. The consuming habits without considering halal and haram, or anything materialistic will lead to temporary satisfaction. Whatever is developed by such people, whether science, technology, creativity, and any innovation, will bring damage or danger to the survival of humans, society, and the natural surroundings.
\end{abstract}

Keywords: fiqh muamalah, food, spiritual development

\section{Introduction}

Islam is a religion that regulates all aspects of human life. The verses stated in the Qur'an and the prophetic tradition (sunnah) are systematized by the scholars in an islamic jurisprudence known as fiqh. Generally, fiqh is divided into two, including ritual jurisprudence (fiqh ibadah) and any transactions among people known as (fiqh muamalah). Fiqh ibadah includes discussion of ritualistic worship such as ritual purity of cleanliness (taharah), declaration of faith (syahadah), prayer (salah), charity (zakah), fasting (shawm) and pilgrimage or performing hajj, while fiqh muamalah is the broadest sense includes discussion and legal opinion (fatwa) of laws relating to human interaction or transactions. Thus, the discussion of fiqh muamalah is wider. If in a day Muslims are only required to pray five times, the rest is the discussion of fiqh muamalah.

Muslims in Indonesia generally very concern and focus on the discussion about fiqh ibadah, but less emphasize on many aspects of it. If it is not understood correctly, doubtful products or even haram might be consumed by the muslims.

This study aims to explain one of the realms of fiqh mu'amalah, namely the impact of food on Muslims' spiritual development. The foci of the problem in this study are: (1) What is the urgency of religiosity for humans?; (2) What are the standards of food in Islam?; and (3) What is the impact of food on the Muslim' spiritual development?

\section{Results and Discussion}

\subsection{Religious Urgency}

Humans are one of the creatures created by Allah equipped with fitrah, so that in his creation and nature there is a natural readiness to understand the beauty of Allah's creation and make it as evidence of the existence of Allah and His oneness. As the word of Allah in surah Al A'raf verse 172, "Am I really your Lord?" They answered "right (You are our Lord), we are witnesses." And Allah states that He takes testimony to them of their position as Lord, so that they will, on the Day of Judgment, not state that they do not know that.

Recognition of the position of Allah as God, clearly firmly planted in his fitrah and has existed in the recesses of his soul since the time of azali. But the combination of the spirit with the body, the human activity with the various demands of his body, and the demands of his life in the world to prosper the earth, has made his knowledge of the position of Allah as God and his natural readiness to force Him to be crushed in ignorance and forgetfulness and hidden in his subconscious recesses. 
So humans need a reminder of this natural readiness, the builder of his negligence, and the generation of his subconscious so that it becomes clear in his consciousness and feelings, this is done by way of human interaction with the universe, contemplation of the wonders of Allah's creation in him and all of Allah's creatures and the whole universe. Among the various factors that can awaken this religion are the dangers and various conditions threatening his life, closing all the gates of his salvation, and there is no daze except Allah. So with his natural impulse, humans return to Allah to ask for help and salvation from Him from various dangers that threaten him. ${ }^{1}$

According to Nasaharuddin in Sulthon, religious is defined as a physical and spiritual activity of humans in religion to respond to religious revelations or teachings which cover all aspects of human life which include aspects of worship, social, psychological (thought, taste, attitude, behavior, personal), politics, economics, values, culture, traditions and so on in totality to achieve the highest service or servitude to the creator. ${ }^{2}$

Furthermore, according to Zakiah in Kurniawan, it is said, the development of one's true religion begins at the age of childhood through his life experiences in childhood, in the family, at school, and in the community. The more experience that is religious (under religious guidance) or religious elements, the attitudes, actions, behavior, and ways of dealing with life will be following religious teachings. ${ }^{3}$

Judging from the two opinions that have been stated above, it can be said briefly that religious is an activity that involves aspects of the human body and spirit, which although initially based on one's religious experience in the family, is essentially a transcendent need which in its implementation will require cognitive functions, affection and psychomotor to be compatible with the religion it believes.

In the Islamic context, all Muslims believe that what has been determined by religion, both permissible and forbidden will bring good to their lives. Ibn Qoyyim stated that Allah SWT does not merely forbid something except that Allah has justified the others as a solution due to the prohibition and vice versa. For example, istikharah as a substitute for azlam (drawing fate with arrows), marriage as a substitute for zina, halal livestock as a substitute for forbidden meat, etc.

According to Yusuf Qordlowi, this combination (halal-haram) will always be found in Islam, this shows that Islam will always provide a solution of all narrowness because it is legally declared haram. Then, on the other hand, a halal solution will be found as vast and very beneficial for humans. ${ }^{4}$

\subsection{Food Influence}

Food and drinks are a source of energy and physiological needs that need to be met for the continuation of human life. ${ }^{7}$ An activity or physiological mechanism can explain various psychological aspects that occur, such as one's mood. Food that enters the body is then digested or called the body's metabolic system.

According to Solomon, Berg, and Martin in the Encyclopedia of Islamic Science, metabolism is the whole chemical reaction that makes living things able to carry out their activities. Most of these chemical reactions occur in cells. ${ }^{5}$ The process of digestion of food can also be interpreted as the process of breaking down food substances so that it can be absorbed (absorbed) by the digestive tract. This process includes taking food (prehension), ruminating (mastication), swallowing (deglutition), digestion and removal of digestive remnants (egestion). At this stage of digestion, there is mechanical, enzymatic, and macrobiotic digestion of food. The digestive process occurs to take food molecules or particles such as glucose, fatty acids, and amino acids that are readily absorbed by the digestive tract mucosa. The food is then circulated through the circulation system to be circulated and used by the body's cells as a material for metabolism as a source of energy (energy), builders (structural) and functional molecules (hormoneenzymes) and other body needs. ${ }^{6}$

Human cells both in the skin, muscles, bones, and eyes all experience rejuvenation every seven years. Except for nerve cells. And in this period, 9 out of 10 brains develop. If nerve cells change every seven years, they will change a person's characteristics. Therefore, an older child, his personality will grow constantly (steady) because the nerve cells do not increase and not decrease.

As an organ controlling behavior, nerves are centered on the human brain. The human brain is composed of about 100 billion nerve cells with complex functions as the control center for all human activities. The brain consists of three parts, namely the cortex, limbic system, and brain stem. ${ }^{7}$ 
Specifically, this research emphasizes the limbic system (the middle part of the brain) as the center of human affection control, the limbic system is a system consisting of subsystems that function to back up human emotions. The limbic system consists of the structure of the hypothalamus, amygdala, and hippocampus. The limbic system functions to produce feelings, regulate hormone production, maintain homeostasis (adaptability), thirst, hunger, sex drive, pleasure centers and also long-term human memory. ${ }^{8}$

As every food affects the organs of the body, so does the limbic. Foods that are good for the nervous system are in addition to having nutritionally balanced, of course, foods that contain omega-3 fatty acids (found in fish, walnuts, broccoli, flaxseeds and nuts). Foods that contain vitamin $\mathrm{B}$, green or colored vegetables, complex carbohydrates, and drink two liters of water per day or the equivalent of eight glasses per day.

The amygdala nerve and the hypothalamus always work together to produce emotions (mood). It is these nerves that work when assessing good or bad food for body condition. When we perceive food as bad, the amygdala will be active and make ourselves tense and uncomfortable so that it affects emotions and makes our mind chaotic. ${ }^{12}$ Worse, there are still many people who consume food or drink or illegal drugs such as drugs. Drug consumption greatly affects brain damage. Initially, users will feel relaxed, happy, calm, confident and feeling high or called rollercoaster feeling. Behavior caused by any type of narcotic substance will interfere with nerve transmission signals called neurotransmitters in the central nervous system (brain). Then the user will automatically experience damage to cognitive function (thinking power and memory), affective function (feelings and mood), psychomotor (movement behavior), compilation of medic against physical (abnormalities of lungs, kidneys, liver, heart), mental disorders, (damage to social functions, work or school and not able to control themselves. Insomnia, irritability, emotional and aggressive). ${ }^{9}$

\subsection{Impact of Food on Religious Systems}

The discussion of food in Islam is not only enough to pay attention to the nutritional content, protein, carbohydrate, fat, omega or vitamins alone. More than that, a Muslim must consider halal or haram food. Allah SWT gives such great treatment to humans so that what $\mathrm{He}$ has established and created on this earth for believers is not enough with halal only, but must be tayyib (good). As the Word of Allah in surah Al Baqarah: 168. "O people, eat from halal and also good food, and do not follow the steps of Satan, truly he is a real enemy for you".

According to the Quraish Syihab, in this verse Allah wants to call on all people including the disbelievers, it is as if Allah said, "O disbelievers, eat all of you halal food that is good again, and do not follow the steps of Satan". Why is that? Because the truth is Satan is a real enemy to you. Human ancestors namely Adam and his wife were deceived through the door of food, indeed, Satan only asks that we do acts that pollute the soul that have a bad impact even without worldly legal sanctions such as lying, arrogant and spiteful, and despicable acts that are actions that are not in line with religious guidance and common sense. Especially acts that have been set worldly sanctions such as zina and murder.

Furthermore, what is meant by halal?

Halal (Arabic: Halla, Yahillu, Hillan = liberating, releasing, breaking up, dissolving and allowing). In terms of, 1). Halal is anything that causes no punishment for using it. 2). Something that can be done according to syara'. Other expressions that refer to halal are tayyib, al khabits, mubah, and jaiz. As for the terms, the definition of halal is:

"any food which is not from or do not contain any part of animals forbidden by Islamic law or animals that are not slaughtered according to Islamic law does not have any impure substance considered by Islamic law, is not prepared, processed or manufactured using equipment which are not free from impurities as defined by Islamic law"(Halal Portal Malaysia. $2011)^{10}$

Based on the two definitions above, then the halal aspect of food is not only seen from the substance, but also at all stages of its processing namely starting from selecting raw materials, preparation, processing, packaging, storage, and transportation. All of these stages must be carried out with halal treatment.

According to Quraish Shihab halal food is divided into two, namely halal substances and not halal substances, halal alone is not necessarily good for eating, halal must be accompanied by halal activities in the process, as explained in surah $\mathrm{Al}$ Baqarah verse 188, "do 
not eat your fellow possessions by vanity". Satan originally invites us to not take care of ourselves when it comes to eating, in terms of the lust of the stomach and eventually protracts into infidelity. Besides, the Prophet said in a hadith:

"O Sa'ad, fix your food, surely you will be made Allah of those who accepted pray. For Allah, the soul of Muhammad is in His grasp, actually, a man who throws an illicit bribe in his stomach, will not receive his charity for forty days. Whoever among the servants of Allah grows his flesh from illicit wealth and usury, fire is better for him"

Regarding the interpretation of the Surah Al Baqarah, Hamka said that food also determines the subtleties or rudeness of one's mind. People who are dirty inside will not be able to clean their prayers. ${ }^{17}$ In another hadith the Prophet emphasized:

"Indeed, the halal is clear, as the haram is also clear. In between, there are cases of doubtfulness - which are still vague - that is unknown to most people. Whoever avoids the case of doubtfulness, he has saved his religion and honor. Whoever falls into the case of doubtfulness, then he can fall into the case of haram. As there are shepherds who herd cattle around the haram land that almost plunged them. Know, every king has a haram land and Allah's haram land on this earth are things that he forbids. Remember in the body there is a lump of meat. If he is good, then the whole body will go well. If he is damaged, then the entire body will also be damaged. Remember that lump of meat is the heart". (Narrated by Bukhari and Muslim)

When viewed from the matan hadith, the Prophet first explained the concept of halal, haram and doubtfulness, then explained the condition of the heart. Indirectly, this hadith implies to us that consuming food or products that are halal, haram, or doubtfulness, will greatly affect the condition of the heart or psychic and even one's spirituality. He said because halal and haram were detailed, both in the Qur'an and the hadith. The doubtfulness category is for something difficult to identify halal and forbiddenness, because of a reason. For something that has fallen into this category, by religion, it is recommended to be careful and even leave it, because approaching something doubtful will fall to the unlawful. On the other hand, guarding yourself against doubtfulness things means only being bound to the halal.
Muslims are required to recognize the quality of food or products consumed because this impacts on its religious. Although food is material and individual religious is immaterial, religious ultimately demands action, especially in ritual worship. Ritual in religion is seen as a manifestation of spirituality in the form of structured, systematic, repetitive actions, involving aspects of motoric, cognition, affection which are carried out according to a particular procedure both individually and communally. ${ }^{11}$ Thus, because of the religious in this particular ritual worship involving affective, cognitive and psychomotor functions, how can it possibly run perfectly when haram food enters its mouth?

A study proves that humans consist of three aspects namely jismiyah, nafsiyah, and ruhiyah. Jismiyah namely the entire physicalbiological organs, glandular system, and nervous system. The aspect of nafsiyah is the overall human qualities that are typical of human beings which contain the dimensions of al-nafs, al-'aql, and al-qalb. And aspects of ruhiyah, namely the overall potential of the human psychic noble radiating from the dimensions of al-ruh and al-fithrah. Proportionally, nafsiyah occupies a position between jismiyah and ruhiyah, because jismiyah comes from objects (matter), so it tends to direct the nafsiyah of humans to enjoy material pleasure. While ruhaniyah comes from God so he always invites the human passion to go to God. People who like to commit immorality means that their lives are directed by jismiyah or temporary material pleasures. Whatever is developed by such people, whether science, technology, creativity, and any innovation, will bring damage or danger to the survival of humans, society, and the natural surroundings. Conversely, people who always try to leave immorality so that their breath is directed by a spirit that always goes to his God, the science and technology brought and developed by him will always be interpreted and imbued by the divine nur attached to him an attitude of trust and responsibility, both individual and social responsibility. Also, he can account for all the deeds of his deeds before his Lord, as well as solidarity with each other, other creatures as well as the surrounding nature. ${ }^{12}$

In the end, no matter how smart we sort out halal and good food for our own, still food that is already in the form of packaging 
products especially those provided by the food industry, will depend very much on the efforts of the country to carry out protection for Muslims, the country is obliged to ensure halal all food products to placate Muslims as consumers. The country must be able to become a stabilizer between the needs of Muslims and the interests of entrepreneurs to achieve common goals. ${ }^{13}$

\section{Conclusion}

Religion is a transcendent need of humans, because humans are born into the world already provided fithrah by Allah, namely the tendency in his nature there is a natural readiness to understand the beauty of Allah's creation and make it as evidence of the existence of Allah and His oneness.

Food is a source of energy and the physiological needs of humans are digested and metabolized, changed by the body's chemical processes and converted into blood cells that spread throughout the body including limbic nerve cells as a central regulator of human behavior.

1 Ahmad Husain Salima. Menyembubkan Penyakit Jiwa dan Fisik. Pg. 67-68

2 Sulthon. Pola Keberagamaan Kaum Tuna Netra dan Dampak Psikologis Terhadap Penerimaan Diri. Pg. 2

${ }^{3}$ Andree Tiono Kurniawan. Perkembangan Jiwa Agama pada Anak. Pg. 2

${ }^{4}$ Sains Ensiklopedi. Ensiklopedi Sains Islami. Pg. 28

${ }^{5}$ Mohd Izhar Arif, et al. Najis (Tinja) Manusia dari prespektif sains dan Islam serta amalan pemakanan Sunnab

${ }^{6}$ Ensiklopedi Sains Islami. Pg. 28

${ }^{7}$ Heru Nurcahyo. Sistem Pencernaan Makanan. Pg. 2

${ }^{8}$ Euis Heryati dan Nur Fauziah. Psikologi Faal. Pg. 13

9 Rezky A. Yatsab, et al. Hubungan Kinerja Otak dan Spiritualitas Manusia Diukur Dengan Menggunakan Indonesia Spiritual Health Assessment Pada Pemuka Agama di Kabupaten Halmahera Tengah. Pg. 4

${ }^{10}$ KOMPAS Life Style. The date 20/11/2019.

Mengapa Makanan Bisa Mempengarubi Mood Kita?

Accessed on Tuesday, 26 ${ }^{\text {th }}$ November 2019. At. 17.31

${ }^{11}$ BNN. Dampak dan Babaya Narkoba: Pg. 28-30

${ }^{12}$ Ensiklopedi Hukum Islam. Pg. 505-507

13 Siti Salwa BTE MD. Sawari. The Relation of Halal Food Consumption and Psychological Features of
Muslim Students in Malaysian Public Universities. Pg. 38

14 Muflih BK Ahmad, et al. The Concept and Component of Contaminated Animals (Al Jalalah Animals). Pg. 4

${ }^{15}$ Hamka. Tafsir Al Az̧ar Juz 1, 2, 3. Pg. 311-314

${ }_{16}$ Ibid. Rezky A. Yatsab Pg. 4

${ }^{17}$ Muhaimin. Pengembangan Kurikulum Pendidikan

Agama Islam. Pg. 47-48

${ }^{18}$ Lies Afroniaty. Analisis Ekonomi Politik

Sertifikasi Halal oleh Majlis Ulama Indonesia. Pg. 4

\section{References}

Afroniyati, L. (2014). Analisis Ekonomi Politik Sertifikasi Halal oleh Majlis Ulama Indonesia. Jurnal Kebijakan dan Administrasi Publik, 18(1).

Ahmad, Muflih, B. K. et al. (2017). The Concept and Component of Contaminated Animals (Al Jalalah Animals). International Food Research Journal 24.

Arif, M. I. et al. (2018). Najis (Tinja) Manusia daripada Prespektif Sains dan Islam serta Amalan Pemakanan Sunnah. Sains Malaysiana, 47(6).

BADAN NARKOTIKA NASIONAL. (2015). Dampak dan Bahaya Narkoba. Jakarta: PT. Tirta Asih Jaya

Hamka. (2015). Tafsir Al Azhar Juz 1, 2, 3. Depok: Gema Insani Press

Heryati, Euis dan Nur Faizah R. (2008). Psikologi Faal. Bandung: Diktat Kuliah Ilmu Pendidikan. Universitas Pendidikan Indonesia.

KOMPAS-Life Style. (2019). Mengapa Makanan Bisa Mempengaruhi Mood Kita?. Diakses pada Hari Selasa, 26-112019. Pukul. 17. 31

Kurniawan, Andree Tiono. (2015). Perkembangan Jiwa Agama pada Anak. Sekolah Tinggi Agama Islam (STAIN) Jurai Sewo Metro Lampung. Vol. 1. Edisi. 1

Muhaimin. (2005). Pengembangan Kurikulum Pendidikan Agama Islam. Jakarta: PT. Raja Grafindo Persada.

Nurcahyo, Heru. (2005). Biologi SMA Kelas 1. Sistem Pencernaan Makanan. Kalasan: Dosen Jurdik Biologi FMIPA UNY. 
Sains Ensiklopedi. (2015). Ensiklopedi Sains Islami Biologi-2. Tangerang: PT. Kamil Pustaka.

Salim, Ahmad Husain. (2009). Al Maradh Wasy Syifa Fil Quranil Kariim (Diterjemahkan: Menyembuhkan Penyakit Jiwa dan Fisik. Penerjemah: Ali Nurdin). Depok: Gema Insani Press.

Sawari, Siti Salwa BTE MD. (2017). The Relation of Halal Food Consumption and Psychological Features of Muslim Students in Malaysian Public Universities. Thesis. Faculty of Islamic Civilization. Universiti Teknologi Malaysia.

Shihab, Quraisy. (2002). Tafsir Al Mishbah, Pesan, Kesan dan Keserasian Al Quran. Vol. 1 dan 2. Jakarta: Lentera Hati.
Sulthon. (2016). Pola Keberagamaan Kaum Tuna Netra dan Dampak Psikologis Terhadap Penerimaan Diri. Sekolah Tinggi Agama Islam Negeri (STAIN) Kudus. 4(1).

Wahab, Muhammad Abdul. (2018). Pengantar Fiqih Muamalat. Jakarta: Rumah Fiqih Publishing.

Yatsab, Rezky A. et al. (2014). Hubungan Kinerja Otak dan Spiritualitas Manusia Diukur Dengan Menggunakan Indonesia Spiritual Health Assessment Pada Pemuka Agama di Kabupaten Halmahera Tengah. Jurnal e-Biomedik. Fakultas Kedokteran Universitas Sam Ratulangi Manado, (2)2. 